\title{
Evaluation of Mean Platelet Volume and Other Complete Blood Count Parameters in Children with Atopic Asthma
}

\author{
Atopik Astımlı Çocuklarda Ortalama Trombosit Hacmi ve Diğer Tam \\ Kan Sayımı Parametrelerinin Değerlendirilmesi
}

\section{Dilek GIRAY1 id , Mehmet ÖZDEMIR² id \\ ${ }^{1}$ Department of Pediatric Cardiology, Mersin University School of Medicine, Mersin, Turkey \\ ${ }^{2}$ Department of Pediatric Allergy, Medeniyet University School of Medicine, İstanbul, Turkey}

\section{ABSTRACT}

Objective: Allergic diseases are increasing in developed countries. Recent studies show that platelets (PLTs) may also be responsible for the development of allergies. The aim of the present study was to investigate whether allergic diseases are related to the levels of mean platelet volume (MPV) and other complete blood count (CBC) parameters.

Method: In the present study, 337 pediatric patients (aged 2-18 years) who were admitted to the pediatric allergy clinics with a diagnosis of atopy, which was supported with the positivity of at least one skin prick test and/or total $\operatorname{IgE}$ and/or allergen-specific $\mathrm{IgE}$, were included. The results of the patients including MPV and other CBC parameters and total IgE values were compared with 120 healthy sex and age-matched children.

Results: There was no difference in hematocrit counts between the groups, but the hemoglobin level was higher in patients. The mean corpuscular volume was lower in the study group, which was not statistically significant. The white blood cell count and thrombocyte count of the patients were higher than those of the controls, but were not statistically significant. The MPV values were significantly lower in the patient group. There was a negative correlation between the MPV values and the thrombocyte counts in the study group. Finally, the MPV values were significantly higher in patients $\geq 6$ years and females in the study group.

Conclusion: PLTs cause inflammation by secreting mediators in children with allergy. When the thrombocyte count increases, the MPV decreases reversely. Thus, the MPV may be an effective and inexpensive indicator in the process of inflammation, but long-term studies are needed to evaluate asymptomatic and exacerbation periods.

Keywords: Atopic diseases, allergy, MPV, platelet count

\section{öz}

Amaç: Alerjik hastalıklar özellikle gelişmiş ülkelerde giderek artan sıklıkta görülmeye başlamıştır. Yakın zamanda yapılan çalışmalar alerji gelişiminde trombositlerin de rol aldığını göstermektedir. Bu çalışmada alerjik hastalıkların ortalama trombosit hacmi (MPV) seviyesi ve diğer tam kan sayımı (TKS) parametreleri ile ilişkili olup olmadığının araştırılması planlanmıştır.

Yöntem: Pediatrik Alerji Kliniğine başvuran atopi tanısı konumuş 337 hasta (2-18 yaş arası) çalışmaya alındı. Atopi tanısı deri prick test ve/veya total IgE ve/veya alerjen spesifik IgE testlerinden en az birinin pozitif olması ile desteklendi. Hastalardan elde edilen MPV ve diğer TKS parametreleri ile total $\operatorname{IgE}$ değerleri yaş ve cinsiyet yönünden benzer 120 sağlıklı çocuğun değerleri ile karşılaştırıldı.

Bulgular: Gruplar arasında hematokrit değerleri açısından anlamlı fark yoktu ancak hemoglobin değeri hasta grubunda istatistiksel olarak daha yüksek bulundu. Ortalama eritrosit hacmi anlamlı olmamakla birlikte çalışma grubunda daha düşük saptandı. Beyaz küre ve trombosit sayısının hastalarda istatistiksel olarak anlamlı olmamakla birlikte yüksek olduğu görüldü. Hastaların MPV değeri ise anlamlı olarak düşük izlendi. Çalışma grubunda MPV ile trombosit sayısı arasında negatif bir korelasyonun olduğu belirlendi. Son olarak çalışma grubunda MPV değerinin kızlarda ve $\geq 6$ yaş hastalarda anlamlı oranda yüksek olduğu görüldü.

Sonuç: Alerjik çocuklarda trombositler mediatör salgılayarak inflamasyona neden olurlar. Trombosit sayısı arttıkça MPV buna ters olarak azalır. Bu nedenle MPV inflamasyon sürecinin etkin ve ucuz bir göstergesi olabilir, ancak asemptomatik ve alevlenme dönemlerini de değerlendiren uzun soluklu çalışmalara ihtiyaç vardır. Anahtar Kelimeler: Atopik hastalıklar, alerji, MPV, trombosit sayısı

\section{Introduction}

Asthma is the most common atopic disease in childhood and has a seasonal tendency. Genetic and environmental factors play roles in the development of atopy. The prevalence of asthma and other atopic diseases is increasing in the recent decade in developed countries (1). Environment and air pollution, childhood infections, exposure to cigarette smoke, decrease in exercise, and changes in dietary habits are suggested to be responsible for this increase. However, the genetic factors that predispose to atopy could not be fully explained yet (2).

Cite this article as: Giray D, Özdemir M. Evaluation of Mean Platelet Volume and Other Complete Blood Count Parameters in Children with Atopic Asthma. Bezmialem Science 2018; 6(3): 181-5. 
The most sensitive diagnostic method is history of the disease. Skin, total IgE, allergen-specific IgE, complete blood count (CBC), and provocation tests are also used in diagnosis $(3,4)$. The skin prick test is recommended owing to its high sensitivity, low cost, and fast result in epidemiological studies. On the other hand, specific IgE measurements on the blood are important owing to their quantitative and repeatable. The total $\operatorname{IgE}$ levels are usually used in the daily routine as a first-line measurement. However, the total IgE levels may be high in some patients with no atopy or may be low in some patients with atopy. Thus, the diagnostic value of total IgE decreases in atopy. Provocation tests are not suitable for routine use $(1,3,4)$.

Respiratory allergens varying by geographic regions cause the development of asthma by triggering allergic inflammation of the nasal and bronchial mucosa. Thus, it is important to specify allergens in different regions that cause sensitization in patients with atopy. Therefore, measures can be taken to reduce the morbidity of allergic diseases, and it may be possible to prevent or delay development of disease in sensitized individuals.

In asthma, airway inflammation leads to symptoms, and many inflammatory cells and mediators play roles in these characteristic inflammatory changes (1). In addition to T helper 2 cells, mast cells, and eosinophils, platelets (PLTs) have been shown to be an important component $(2,5-8)$. Activated PLTs synthesize several inflammatory factors $(2,5)$. The mean platelet volume (MPV) can be used as a marker of this activation. Moreover, it is known that there is an inverse relationship between PLT count and MPV in a healthy population (6).

Changes in value of MPV, PLT function, and quality were demonstrated in many studies (5-8). However, the relationship between childhood atopic asthma and inflammatory response affecting the MPV values was not studied sufficiently in the literature. In addition, we know that $\mathrm{CBC}$ parameters change in inflammatory diseases. As asthma is an inflammatory disease,

Table 1. Total IgE reference ranges by age in groups

\begin{tabular}{l|c} 
Age & Reference ranges $(\mathrm{IU} / \mathrm{mL})$ \\
$0-6$ months & $0-1.5$ \\
$7-12$ months & $0-15$ \\
13 months-5 years & $0-60$ \\
$6-9$ years & $0-90$ \\
$10-15$ years & $0-200$ \\
$\geq 16$ years & $0-100$
\end{tabular}

Table 2. Evaluation of atopy parameters in the study group

\begin{tabular}{|l|c|r|}
\hline Parameter & Positive & Negative \\
\hline Skin prick test positivity, n (\%) & $292(86.6)$ & $45(13.4)$ \\
\hline Specific IgE positivity, n (\%) & $14(18.4)$ & $62(81.6)$ \\
\hline Total IgE positivity, $n(\%)$ & $246(72.9)$ & $91(27.1)$ \\
\hline
\end{tabular}

we aimed to determine if MPV and other CBC parameters change in childhood asthma and compare them with levels of healthy children. Furthermore, we aimed to determine if MPV may be indicator of inflammation in patients with asthma.

\section{Methods}

This was a retrospective study performed in the clinics of pediatric allergy from October 2012 to June 2013. The results of skin prick test and/or total $\mathrm{IgE}$ and/or allergen-specific IgE of the patients were recorded from archives and diagnosis of atopy supported with positivity of at least one of them. Patients had no chronic illness other than asthma and were aged 2-18 years. The recorded results of the patients including MPV and other CBC parameters were compared with sex- and age-matched healthy children who were admitted to the Healthy Child Control Polyclinic for general medical examination. The study was completed with 337 (145 female and 192 male) pediatric patients. The average age of the children was $7.82 \pm 3.37$ years. The control group included 120 (52 female and 68 male) healthy children. The mean age of the healthy children was $7.17 \pm 4.12$ years. The skin prick test was performed in all patients. Informed consent was obtained from all patients. Medeniyet University School of Medicine Ethics Committee approved the study protocol (2014/0010).

Table 1 shows the total IgE levels that are accepted as positive by age (9).

The specific IgE levels of the patients had been studied using the Pharmacia CAP System RAST FEIA. The results read from the FlouroCount were evaluated as $\mathrm{IU} / \mathrm{mL}$ according to the standard IgE calibrator of the World Health Organization. The allergen-specific antibody value of $\geq 0.35 \mathrm{IU} / \mathrm{mL}$ was accepted as positive, but that of $<0.35 \mathrm{IU} / \mathrm{mL}$ was accepted as negative.

\section{Statistical analysis}

Number Cruncher Statistical System (NCSS) 2007 \& Power Analysis and Sample Size (PASS) 2008 Statistical Software (UT, USA) was used for statistical analysis. Data were analyzed by using descriptive statistical methods (mean, standard deviation, frequency, rate, minimum, and maximum) and also by using Student's t-test for comparison of quantitative data. Pearson correlation analysis was used to evaluate the relationships of parameters. A p value $<0.05$ was considered as significant.

\section{Results}

There were no statistical differences in age and gender between the groups $(p>0.05)$. In the study group, $72.9 \%(n=246)$ of the patients' $I g E$ values were higher than normal for age, which were accepted as positive. The skin prick test was positive in $86.6 \%(n=292)$ of the patients. At least one specific IgE test was performed in 76 of the patients, and any specific IgE test positivity was found in $18.4 \%(n=14)$ of these cases (Table 2$)$.

The hemoglobin levels of the study group were found to be significantly higher than those of the control group $(\mathrm{p}<0.05)$, but there was no significant difference in hematocrit values ( $p>0.05)$. The MCV values of the patients were slightly lower 
Table 3. Comparison of demographic characteristics, MPV, and other CBC parameters between the groups

\begin{tabular}{|c|c|c|c|}
\hline Parameters ( $n=457$ ) & $\begin{array}{c}\text { Study }(n=337) \\
\text { Mean } \pm S D\end{array}$ & $\begin{array}{c}\text { Control }(n=120) \\
\text { Mean } \pm S D\end{array}$ & ${ }^{\mathrm{a}} \mathrm{p}$ \\
\hline Age (year) & $7.82 \pm 3.37$ & $7.17 \pm 4.12$ & 0.119 \\
\hline Gender ( $\mathrm{n}$; female/male) & $145 / 192$ & $52 / 68$ & 0.974 \\
\hline Leukocyte $(\times 103 / \mu \mathrm{L})$ & $9972.70 \pm 3330.16$ & $9456.90 \pm 3329.22$ & 1.151 \\
\hline Hemoglobin (g/dL) & $12.43 \pm 0.97$ & $12.21 \pm 1.15$ & $0.043 *$ \\
\hline Hematocrit (\%) & $37.34 \pm 2.91$ & $36.74 \pm 3.23$ & 0.065 \\
\hline $\mathrm{MCV}(\mathrm{fL})$ & $79.37 \pm 5.12$ & $79.73 \pm 5.94$ & 0.563 \\
\hline PLT $(\times 103 / \mu L)$ & $307958.46 \pm 74133.56$ & $298605.04 \pm 81368.20$ & 0.250 \\
\hline MPV (fL) & $8.65 \pm 0.83$ & $9.82 \pm 0.93$ & $0.003 *$ \\
\hline Female $(n=145)$ & $8.78 \pm 0.88$ & - & $0.011^{*}$ \\
\hline Male $(n=192)$ & $8.56 \pm 0.78$ & - & \\
\hline
\end{tabular}

Table 4. Evaluation of the MPV values according to age in the study group

\begin{tabular}{|c|c|c|c|}
\hline & Age $<6$ years $(n=94)$ & Age $\geq 6$ years $(n=243)$ & \\
\hline Parameters $(n=337)$ & Mean \pm SD & Mean \pm SD & $p$ \\
\hline MPV & $8.35 \pm 0.69$ & $8.76 \pm 0.85$ & $0.001^{*}$ \\
\hline
\end{tabular}

than those of the control group, which were not statistically significant $(\mathrm{p}>0.05)$ (Table 3).

The number of PLTs in the study group was found to be higher than those of the control group, but the difference was not statistically significant $(p>0.05)$. However, the MPV values of the patients were found to be statistically lower than those of the controls $(p<0.01)$. Moreover, the MPV values of the female patients were statistically higher than those of the male patients in the study group $(\mathrm{p}<0.01)$ (Table 3$)$. Patients were divided into two groups according to skin prick test positivity, and the MPV levels were compared, and there was no significant difference between the groups $(\mathrm{p}=0.06)$.

The MPV values of the patients $<6$ years were found to be significantly lower than those of the cases $\geq 6$ years $(p<0.01)$ (Table 4).

A statistically significant negative relationship was found between MPV and PLT values at the level of 32.7\%, suggesting that PLT value increases when MPV value decreases in patients $(\mathrm{r}=-0.327 ; \mathrm{p}<0.01)$.

\section{Discussion}

Allergic diseases are IgE-mediated immune responses of tissues as a result of repeated exposure with the same allergen. Atopy is an important risk factor in the development of allergic diseases. The presence of atopy in individuals should be proven by positive response in one of the epidermal skin tests, high level of serum total $\operatorname{IgE}$, or allergen-specific $\operatorname{IgE}(1,3,4)$.
Chemokine, cytokine, and thrombopoietin levels of plasma in individuals with atopy have been found to be higher than those with no atopy after allergen exposure. Thrombocytes play important roles in airway inflammation because thrombopoietin is released by PLTs $(5,6)$. Kowal et al. (7) studied the activation of PLT in patients with asthma after exposure to house dust mites. They reported that in patients with asthma, prolonged airway inflammation after allergen exposure is associated with intravascular PLT activation $(7,8)$. Many mitogens and enzymes secreted by PLTs may directly contribute to airway remodeling. After an increase in thrombopoiesis, bronchial smooth muscle hypertrophy, proliferation of myofibroblasts, and subepithelial fibrosis occur $(5,7)$. Thrombopoietin is the cytokine that plays the most critical role in the regulation of PLT production and maturation. KemonaChetnik et al. (10) studied the number of PLTs, percentage of reticulated PLTs (young thrombocytes), thrombopoietin, and interleukin 6 levels of plasma in patients with asthma. They found that PLT count and percentage of reticulated PLTs are significantly higher in patients with asthma than in controls. Furthermore, they reported that thrombopoietin concentration is higher in patients, which is not statistically significant (10). In our study, PLT count was found to be slightly increased in patients with asthma, but was not significant. This difference between the studies was thought to be due to the severity of the disease in patients included. In our study, patients were in the remission period, and patients with severe asthma and patients with asthma attack were not included. Even though not being a marker of inflammation, it can be said that in asthma, PLT count increases. 
Some studies remark that PLT parameters are similar in males and females and also do not change by age $(11,12)$. In our study, the MPV values of females were found to be significantly higher than those of males. Moreover, the MPV value is lower in patients $<6$ years in the study. This may be explained as atopic asthma as it is more frequent in males in preadolescence, and attacks are also more frequent in early ages.

Tuncel et al. (13) could not find a significant difference in the MPV values during the asymptomatic period and period of attack in patients with asthma. In addition, they did not find any difference in the MPV level between the patients with asthma and the control group. Conversely, Akelma et al. (14) studied the MPV levels in pediatric population with chronic spontaneous urticaria. They found decreased MPV levels in the patient group. Similarly, in our study, the MPV values of patients with asthma were found to be significantly lower than those of the control group. Numerous publications are available in evaluating the MPV level of chronic inflammatory diseases, such as familial Mediterranean fever, ulcerative colitis, Crohn's disease, rheumatoid arthritis, systemic lupus erythematosus, indicating that the MPV level is significantly decreased in chronic inflammation (15-21). On the contrary, some other studies showed an increased level of MPV in pathological conditions, such as atherosclerotic renal artery stenosis, diabetes mellitus, obesity, hyperlipidemia, hypertension, and sepsis (22-24). This increase was thought to be associated with thrombocytopenia that is seen in these pathological conditions because in thrombocytopenia, young PLTs are released to the peripheral circulation, and MPV increases. Dogru et al. (25) studied the PLT and MPV levels in 162 pediatric patients, and they reported that both increase in asthma. However, they also said that in exacerbation periods, the MPV values decrease when compared with asymptomatic periods of the patients, and they could not fully enlighten this controversial result.

Platelet mass is equal to the multiplied PLT count and PLT volume. Since PLT mass is constant, there is an inverse relationship between PLT count and MPV. Bessman et al. (17) researched this correlation in children with nephrotic syndrome and also in active and remission periods of the disease. They showed a significant negative correlation between PLT count and MPV. A similar relationship was shown by studies of patients with chronic idiopathic thrombocytopenic purpura, iron deficiency anemia, thalassemia, sepsis, chronic renal failure, chronic obstructive pulmonary disease, and cystic fibrosis (17-20, 24). Moreover, it is reported that in these chronic lung diseases, the MPV level can be used as a reliable negative acute phase reactant especially in the activation period of the illness (19).

We investigated whether there was a correlation between MPV and the number of PLT in the study group and also found a significant negative relationship between MPV and PLT values. Thus, it is thought that MPV can be a marker of circulating PLT activation in the process of airway inflammation in children with asthma.

Other basic parameters obtained from $\mathrm{CBC}$ are red blood cell (RBC) and white blood cell (WBC) counts, morphol- ogy, and sizes. WBC is also an indicator of inflammatory and immunological conditions. Although the WBC of the study group was higher than that of the control group, there was no statistically significant difference. This was thought to be due to asthma being a chronic inflammation, not being an acute illness. Moreover, patients with severe asthma were not included in the study. Some other studies measuring inflammation with the acute phase reactant, C-reactive protein (CRP), were available. They found that the CRP levels are higher in patients with asthma than in the control group, but had reported no significant between the groups, suggesting that asthma is not an acute disease $(26,27)$.

The hemoglobin levels of patients with asthma were found to be higher than those of controls. The hematocrit values were slightly higher in patients with asthma, but the difference was not significant. This was thought to be due to patients with asthma who could have been treated for anemia more frequently than healthy children. To our knowledge, there was no similar study in the literature. Tülübaş et al. (28) found a marked decline in mean corpuscular volume, which is an erythrocyte parameter, in patients with asthma. We found a similar decline, which was not statistically significant. This decline may show that the factors involved in the pathogenesis of asthma may also affect RBC morphology.

\section{Study limitations}

First, we did not study if there was a relationship between the MPV levels and the PLT count in patients during attack and asymptomatic period or not. Second, it was not known that the drugs used in asthma treatment had an effect on these parameters. Finally, children who were admitted to the Healthy Child Control Polyclinic for general medical examination were accepted as the control group. However, there was a possibility of these children being allergic and in the asymptomatic period of disease.

\section{Conclusion}

The present study is important in confirming asthma as an inflammatory disease in which MPV decreases. Our study has the largest population of patient and control groups in the literature performed in childhood asthma. In addition, it is important in confirming MPV as an effective and inexpensive indicator of lower airway inflammation. Other $\mathrm{CBC}$ parameters in daily routine are not good enough as markers.

Ethics Committee Approval: Ethics committee approval was received for this study from the ethics committee of Medeniyet University School of Medicine (2014/0010).

Informed Consent: Written informed consent was obtained from all patients who participated in this study.

Peer-review: Externally peer-reviewed.

Author Contributions: Concept - D.G.; Design - D.G.; Supervision M.Ö.; Resources - D.G.; Materials - M.Ö.; Data Collection and/or Pro- 
cessing - D.G., M.Ö.; Analysis and/or Interpretation - D.G., M.Ö.; Literature Search - D.G.; Writing Manuscript - D.G.; Critical Review - M.Ö.

Conflict of Interest: Authors have no conflicts of interest to declare.

Financial Disclosure: The authors declared that this study has received no financial support.

Etik Komite Onayı: Bu çalışma için etik komite onayı Medeniyet Üniversitesi Etik Kurulu'ndan (2014/0010) alınmıştır.

Hasta Onamı: Yazılı hasta onamı bu çalışmaya katılan tüm hastalardan alınmıştır.

Hakem Değerlendirmesi: Dış bağımsız.

Yazar Katkıları: Fikir - D.G.; Tasarım - D.G.; Denetleme - M.Ö.; Kaynaklar - D.G.; Malzemeler - M.Ö.; Veri Toplanması ve/veya İşlemesi - D.G., M.Ö.; Analiz ve/veya Yorum - D.G., M.Ö.; Literatür Taraması - D.G.; Yazıyı Yazan - D.G.; Eleştirel İnceleme - M.Ö.

Çıkar Çatışması: Yazarlar çıkar çatışması bildirmemişlerdir.

Finansal Destek: Yazarlar bu çalışma için finansal destek almadıklarını beyan etmişlerdir.

\section{References}

1. Valacer DJ. Childhood asthma: causes, epidemiological factors and complications. Drugs 2000; 59: 1-8. [CrossRef]

2. Tavacol H, Rahimi Z, Cheraghi M, Ghatfan F, Baji Z, Rahmani H. A cross-sectional study of prevalence and risk factors for childhood asthma in Ahvaz city, Iran. Postep Derm Alergol 2015; 32: 268-73. [CrossRef]

3. Atkins D, Leung DYM. Diagnosis of Allergic Diseases. In: Kliegman RM, Behrman RE, Jenson HB, Stanton BF, editors. Nelson Textbook of Pediatrics. 18th edition. Philadelphia: Saunders, 2007: 938-42.

4. Ownby DR. Skin tests in comparison with other diagnostic methods. Immunol Allergy Clin North Am 2001; 21: 35567. [CrossRef]

5. Pitchford SC, Page CP. Platelet activation in asthma: integral to the inflammatory response. Clin Exp Allergy 2006; 36: 399401. [CrossRef]

6. Levin J, Bessman JD. The inverse relation between platelet volume and platelet number. Abnormalities in hematologic disease and evidence that platelet size does not correlate with platelet age. J Lab Clin Med 1983; 101: 295-307.

7. Kowal K, Pampuch A, Kowal-Bielecka O, DuBuske LM, Bodzenta-Lukaszyk A. Platelet activation in allergic asthma patients during allergen challenge with Dermatophagoides pteronyssinus. Clin Exp Allergy 2006; 36: 426-32. [CrossRef]

8. Nacaroglu HT, Isguder R, Bahceci SE, Ceylan G, Korkmaz HA, Karaman S, et al. Can mean platelet volume be used as a biomarker for asthma? Adv Dermatol Allergol 2016; 33: 182-7. [CrossRef]

9. Chemistry Insert, Beckman Access Immunoassay System, Total IgE, Beckman Coulter Inc., Fullerton, CA (1998).

10. Kemona-Chetnik I, Bodzenta-Lukaszyk A, Butkiewicz A, Dymnicka-Piekarska V, Kemona H. Thrombocytopoesis in allergic asthma. Pol Arch Med Wewn 2007; 117: 9-13.
11. Dow RB. The clinical and laboratory utility of platelet volume parameters. Aust J Med Sci 1994; 15: 12-5.

12. Bancroft AJ, Abel EW, Mclaren M, Belch JJ. Mean thrombocyte volume is a useful parameter: a reproducible routine method using a modified Coulter Thrombocytometer. Thrombocytes 2000; 11: 379-87.

13. Tuncel T, Uysal P, Hocaoglu AB, Erge DO, Karaman O, Uzuner N. Change of Mean Platelet Volume Values in Asthmatic Children as an Inflammatory Marker. Allergologia at Immunopathologia (Madr) 2012; 40: 104-7. [CrossRef]

14. Akelma AZ, Mete E, Cizmeci MN, Kanburoglu MK, Malli $\mathrm{DD}$, Bozkaya D. The role of mean platelet volume as an inflammatory marker in children with chronic spontaneous urticaria. Allergol Immunopathol (Madr) 2015; 43: 10-3. [CrossRef]

15. Kapsoritakis AN, Koukourakis MI, Sfiridaki A, Potamianos SP, Kosmadaki MG, Koutroubakis IE, et al. Mean platelet volume: a useful marker of inflammatory bowel disease activity. Am J Gastroenterol 2001; 96: 776-81. [CrossRef]

16. Kisacik B, Tufan A, Kalyoncu U, Karadag O, Akdogan A, Ozturk MA, et al. Mean platelet volume (MPV) as an inflammatory marker in ankylosing spondylitis and rheumatoid arthritis. Joint Bone Spine 2008; 75: 291-4. [CrossRef]

17. Bessman DJ, Williams LJ, Glimer PR. Thrombocyte size in health and hematologic disease. Am J Clin Pathol 1982; 78: 150-3. [CrossRef]

18. Yazar B. Nefrotik sendromlu çocuklarda ortalama trombosit hacminin klinik önemi. Uzmanlık Tezi, Ankara: Başkent üniversitesi Tıp Fakültesi, Çocuk Sağlı̆̆ı ve Hastalıkları Anabilim Dali, 2008.

19. Ulasli SS, Ozyurek BA, Yilmaz EB, Ulubay G. Mean platelet volume as an inflammatory marker in acute exacerbation of chronic obstructive pulmonary disease. Polskie Arch Medyc 2012; 122.

20. Uysal P, Tuncel T, Olmez D, Babayigit A, Karaman O, Uzuner N. The role of mean platelet volume predicting acute exacerbations of cystic fibrosis in children. Ann Thorac Med 2011; 6: 227-30. [CrossRef]

21. Gunluoglu G, Yazar EE, Simsek N, Veske NS, Seyhan EC, Altinet $S$. Mean platelet volume as an inflammation marker in active pulmonary tuberculosis. Multidiscip Respir Med 2014; 9: 11. [CrossRef]

22. Brown AS, Hang Y, Belder A, Beacon H, Beeso J, Sherwood R, et al. Diabetics with peripheral vascular disease have increased mean thrombocyte volume and megakaryocyte ploidy. Br Heart J 1994; 71: 178.

23. Kario K, Matsuo T, Nakao K. Cigarette smoking increases the mean trombosit volume in elderly patients with risk factors for atherosclerosis. Clin Lab Haemat 1992; 14: 281-7. [CrossRef]

24. Vincent JL, Yagushi A, Pradier O. Platelet function in sepsis. Crit Care Med 2002; 30: 313-7. [CrossRef]

25. Dogru M, Aktas A, Ozturkmen S. Mean platelet volume increased in children with asthma. Pediatr Allergy Immunol 2015; 26: 817-26. [CrossRef]

26. Çalıkoğlu M, Ünlü A, Tamer L, Çalıkoğlu İ, Polat G. Asᄀtımlı hastalarda serum akut faz protein düzeyleri. Turkiye Klinikleri J Med Sci 2004; 24: 440-4.

27. Dursun F. Ig E, eosinophil, CRP levels and atopy in the asthmatic children. J Health Sci 2007; 16: 80-5.

28. Tülübaş F, Gürel A, Donma MM, Nalbantoğlu B, Topçu B, Mut ZD. Astma ve alerjik rinitli çocuklarda total IgE, C-reaktif protein ve kan sayım parametrelerinin değerlendirilmesi. Dicle Med J 2013; 40: 57-61. [CrossRef] 